\title{
Reformed spirituality in action: The diary of A.D. Luckhoff as praxis
}

\author{
Author: \\ Pieter G.R. de Villiers ${ }^{1}$ \\ Affiliation: \\ ${ }^{1}$ Department of Old and New \\ Testament, University of the \\ Free State, South Africa \\ Correspondence to: \\ Pieter G.R. de Villiers \\ Email: \\ pgdevilliers@mweb.co.za \\ Postal address: \\ 202 Rozenhof, 165 Dorp \\ Street, Stellenbosch 7600 \\ South Africa \\ Dates: \\ Received: 09 June 2011 \\ Accepted: 21 July 2011 \\ Published: 25 Oct. 2011 \\ How to cite this article: \\ De Villiers, P.G.R., 2011, \\ 'Reformed spirituality \\ in action: The diary of \\ A.D. Luckhoff as praxis', \\ HTS Teologiese Studies/ \\ Theological Studies 67(3), \\ Art. \#1109, 10 pages. http:// \\ dx.doi.org/10.4102/hts. \\ v67i3.1109
}

C 2011. The Authors.

Licensee: AOSIS

OpenJournals. This work

is licensed under the

Creative Commons

Attribution License.
This article discusses the praxis of Reformed Spirituality by investigating the diary of Reverend A.D. Luckhoff which he wrote during the Anglo-Boer War as chaplain in the infamous Bethulie concentration camp. The article locates Luckhoff and his diary in the context of Reformed Spirituality and in the study of Spirituality with special attention to their transformative actions on behalf of others and how this, in turn, affected his Spirituality. It points out the diary's significance before it analyses the nature of Luckhoff's Reformed Spirituality as it is evident in his pastoral activities and work ethic, his struggle for justice and dignity, and, finally, his political approach in a difficult situation. In conclusion some remarks are made about the nature of Luckhoff's Reformed Spirituality.

\section{Introduction}

Shortly after the Anglo-Boer war, in 1904, a diary was published with the title, Woman's Endurance. It was written from 21 August to 01 November 1901 by one 'A.D.L. (B.A.)' who describes himself as 'chaplain in the concentration camp, Bethulie, O.R.C. 1901'. It is a remarkable document which provides a first-hand account of the faith experience of a spiritual leader and mystagogue from the Reformed tradition in a context of extreme violence and in the worst time of the war. ${ }^{1}$ The author was the Reverend A.D. Luckhoff, later to become a household name in the Dutch Reformed Church and the larger South African society because of his social consciousness and his welfare work amongst poor White Afrikaners in the Northern Cape, and, afterwards, in the country as a whole. ${ }^{2}$

The diary of Luckhoff provides a unique opportunity to observe the face of Reformed Spirituality in the life of a group of people in the concentration camp in Bethullie. By studying it, one will also have access to Reformed Spirituality in action on a wider scale in church and in society. Luckhoff was exposed to the Reformed faith from his earliest childhood. He was born in 1874 in the parsonage of his father in Colesberg, from a family of pastors from Rhenish, Wesleyan and Dutch Reformed contexts. ${ }^{3}$ With such a family he experienced from his earliest life strong religious influences, but he also had the optimum exposure to different forms of Spirituality within a Protestant context. The influence of this familial context is visible in his vocation and in his decision to train for the ministry, but it is also evident in the evangelical form of Reformed Spirituality that is found in his diary. ${ }^{4}$

Luckhoff completed his theological studies in Stellenbosch in 1900 where his professors at the Seminary were known for their evangelical approach, thereby strengthening the influence of a particular form of Reformed Spirituality that was focused on the interiorisation of faith and a concern for action. After his studies he travelled for six months in Europe, before he finally, on invitation from the Reverend William Robertson, became chaplain in the infamous concentration camp in Bethulie in the Free State. ${ }^{5}$ At a later stage he became the Secretary in charge of the Dutch Reformed Church's welfare department for 27 years from 1916-1943 (Pretorius 2006:iv-v). In this capacity he had a huge influence in the Dutch Reformed church and its massive involvement

1.On various interpretations of the term 'Spirituality', cf. Eire (1990:53), Roten (1994:102) and Schneiders (2005:15-32, 2006:202). The term is used here as understood by Waaijman (2002:305-591; also 2006:1-18). The various forms of Spirituality is a result of its contextualisation in various confessional traditions, as is explained in Holder (2008), Sheldrake (2005, 1999) and Waaijman (2006:20, 48-51, 72-85, 199-200). Calvinist or Reformed Spirituality would be one such tradition, but even within Calvinist Spirituality there are various forms (e.g. a Dutch Reformed and a Reformed Spirituality in South Africa). This article is a second one in a series on spiritualities in South Africa. For the first article on Reformed Spirituality, cf. De Villiers (2009).

2.Cf. the enlightening article of Britz (2007) for more information about Luckhoff's ministry. His work of upliftment is illustrated by the 23 schools he had built in four years' time in small towns in the Northern Cape (Kenhardt, Upington and Kuruman).

3.Cf. Kingston (2005), Randall (2005) and Lane (2005a, 2005b) for discussions of forms of Spirituality that relate to Wesleyan, Rhenish and Reformed Spiritualities. These articles provide a valuable insight in the complexities of the confessional Spiritualities which influenced Luckhoff.

4.This is discussed in more depth at the end of this essay.

5.According to Pretorius (2006:iii) it was Sir Hamilton Gould-Adams, the Deputy Administrator of the Orange River Colony who invited him. Britz (2007:31) states that it was Reverend William Robertson who extended the invitation. Luckhoff $(2006: 1)$ mentions both names in his foreword to the diary. The notorious reputation of the camp is explained by Raath and Louw (1993b). 
in social upliftment, but also, in a time when Reformed Churches had exceptional political clout, in the country as a whole. An indication of his standing and reputation is found in the fact that the University of Stellenbosch awarded him an honorary doctorate in 1946.

Such biographical information already suggests the importance of faith in action in Luckhoff's life, not only in terms of experiencing faith personally, but also in terms of living faith to the upliftment of others. His personal history and his ministry reveal an extraordinary social consciousness and engagement in socio-political issues. They reflect the theoretical insight of Lane (2005:163) on Reformed Spirituality, that, 'The analysis and redemption of social structures ... became an accompanying dimension of Calvinist spirituality'. His diary is an early indication of his Spirituality with its focus on praxis and action - and it stayed that way for the rest of his life.

This article locates Luckhoff and his diary in the context of Reformed Spirituality and in the study of Spirituality with special attention to their transformative actions on behalf of others and how this, in turn, affected his Spirituality. It points out the diary's significance before it analyses the nature of Luckhoff's Reformed Spirituality as it is evident in his pastoral activities and work ethic, his struggle for justice and dignity, and, finally, his political approach in a difficult situation. In conclusion some remarks are made about the nature of Luckhoff's Reformed Spirituality.

\section{The significance of the diary}

Luckhoff's diary is important because of several other reasons. It, first of all, offers an example of the immense challenges that faced the victims of the Anglo-Boer War. It graphically provides an insight by a reliable and trusted community leader of the impact of the war on others and himself. How devastating this experience was, is to be seen already on the level of the form and structure of the diary. The diary moves beyond the shorter notes that merely listed Luckhoff's visits at the beginning, to ever longer, deeply emotional and sometimes even confused passages. The diary has a devastating conclusion when Luckhoff finally fell ill with enteric, ${ }^{6}$ collapsed, and was hospatilised for at least a month. In this time he felt that everyone conspired against him and that only his fellow-pastor was to be trusted. It was a time of 'mental delusion', of 'days of blank', during which his 'chief pastime was to recite the Burial Service' (Luckhoff 2006:67).

The diary thus provides historical evidence on a personal level of the devastating physiological, psychological and spiritual effects of the camp and war and the sacrifices that were made to overcome these effects. This insight is even more important because it is provided by an eyewitness. The diary communicates from an insider's perspective how Luckhoff responded to a situation which was out of hand. He for more than a month. was chaplain in Bethulie for a mere two months and 10 days (21 August 1901 - 01 November 1901) ${ }^{7}$ when the number of deaths reached their highest point. The list of funerals at the end of the diary tells a story of its own. Whilst there were 47 deaths in May, June and July, the numbers for the following months were: August 175; September 236; October 154; November 236 and December 276. For him and his colleagues this devastation practically meant that they had to conduct seventeen funerals on one day. ${ }^{8}$

Luckhoff's experience in this regard should be placed within a larger framework to explain its true nature. The Anglo-Boer War (1899-1902) was one of the deadliest in modern history. In the war 27927 people died in 34 camps. Those who died amounted to $15 \%$ of the total citizens of the Boer Republics. Even more disconcerting was that 22000 of those who died were children under the age of 16 and 4200 were women. In these camps 110000 people - almost half of the population of the Republics - experienced the loss of their family and friends.

The diary of Luckhoff is also a powerful illustration of heroic sacrifices that were made to assist the victims in this situation. Luckhoff responded to the call to help out with the pastoral work in the camp as concerns about the camps were increasingly expressed by church leaders and members in the country and abroad. His diary speaks of the consequences of this reponse mostly on him and his flock. And yet, their experience was a small part of the general situation in which there were 34 camps. Luckhoff was, as chaplain, to some extent in a privileged position. He enjoyed reasonable living conditions, was able to move relatively freely and had some authority to negotiate with camp authorities. If he was devastated by these deaths, how much more would they have affected the residents who were denied such privileges and whose living conditions were appalling. The diary therefore provides a key to understand the collective experience of a nation.

The diary of Luckhoff is, otherwise, important for the study of Spirituality for several other reasons. It gives access to an important form of Spirituality. It provides social, political, historical and religious insights in the Spirituality of Reformed Christianity as a significant and influential confessional group in South Africa with worldwide links and relationships at the beginning of the 20th century. ${ }^{9}$ It helps to

7.Pretorius (2006:vii) writes, 'the diary gives one a shocking revelation of the camp inh 7. tells us of one of the most traumatic moments in Afrikaner history, it is this diary'. It was a time in which not only a vast number of people were killed, but also their livelihood destroyed. Giliomee (2004:209-210) notes that almost the whole of the Free State was scorched, evoking the following comments from the later General Smuts, '[Wherever] the enemy appeared, he carries out indescribable destruction. All houses are burned down, all fields and gardens are utterly destroyed, all cattle and foodstuffs are carried off and all males taken prisoner'. Up to 30000 farms $(60 \%$ of the total number) were destroyed. Losses amounted to almost a third of what the war cost the British (Giliomee 2004:211). This destruction caused widespread poverty which had consequences for many years afterwards (Pauw 1946:64). Cf also Spies (1977), Van Reenen (1973 and 1980), Britz (2007) for the consequences of the war and Pakenham (1979) for a historical discussion.

8.Luckhoff's short, simple remark (2006:19), 'Mr. Becker took funerals, seventeen several in blankets', suggests trauma beyond description.

9.In this essay, Calvinist and Reformed Spirituality are used in a general sense and are understood as referring to the same phenomenon, even though articles like that of Cornick (2005) and and Lane (2005) distinguish between them. 
explain how Reformed Churches regarded the relevance of their faith to its context and world in a situation of war that tested their Spirituality to the hilt. By studying this diary, one is empowered to understand the roots and present nature of Reformed Christianity better, but one also gains insight on Calvinist or Reformed Spirituality in the more general sense of the word. Finally it reveals the practical orientation of Reformed Spirituality and help to explain the involvement of Reformed Spirituality in upliftment.

Luckhoff's diary is, finally, also important because of the light it sheds on the issue of war and violence and how Reformed Christians respond to them. This also will provide valuable material for contemporary discussion of violence and peace, ${ }^{10}$ which, in turn, provides a context for discussing and designing a Spirituality of peace. ${ }^{11}$

\section{The diary as spiritual text}

Luckhoff's diary signifies an important spiritual activity merely as text that has the potential to contribute significantly to the study of Spirituality. This thin diary of the youthful chaplain (only 67 pages long), has not made much of an impression on later generations. In his biographical discussion of Luckhoff in the Christelike Ensiklopedie (Gaum 2007), the former professor in church history at the University of Pretoria, P.B. van der Watt, does not even mention it. Even Pretorius, the respected historian and specialist on the war, notes (2006:iii) that he was only 'vaguely' aware of the diary - though, having read it, regarded it as 'very important and amazing' ${ }^{12}$ It was not only Luckhoff's diary that was treated in this way. There is, for example, the equally unique, but mostly unresearched diary of Rensche van der Watt which provides a fascinating insight in a woman's and conservative Calvinist perspective on the devastating Anglo-Boer war. ${ }^{13}$

Such an attitude illustrates the sceptical view of diaries. They are not always regarded as 'serious' literature, because they are seen as subjective, unreliable and lacking in conceptualisation (Waaijman 2002:929). Such an attitude has changed because of major developments in the philosophy of science, which also influenced the study of Spirituality. ${ }^{14}$ In recent academic study of Spirituality, diaries are seen as a primary source for research on Spirituality (cf. Waaijman 2002:923). A diary, as Waaijman notes, represents a form of

10.For the method, cf. Waaijman (2002:535-548). He (2002:535) writes that the discipline of spirituality must be 'epistemologically situated within the cognitive domain which reflects on human praxis'. It assumes a 'phenomenological approach which uses a strategy of description in demarcating the form, describing the which uses a strategy of description in demarcating the form, describing the
external horizon and discloses the internal horizon' (Waaijman 2002:599). Praxis is a key word in philosphy and spirituality which has been studied in a sophicated way, amongst others by Arendt (1958) and Boff (1987).

11.Cf. Waaijman (2002:966) and De Villiers (2008a, 2008b, 2009a and 2009b) for a full discussion of a Spirituality of peace and for Biblical material as building blocks for such a Spirituality. For Van der Walt's diary, see Hamman (1965).

12.The facsimile version of this diary (2006), provided with an introduction by Pretorius, is quoted in this essay. The original appeared in 1904. It was due to the insight of Stassen, the publisher of the new edition, that the diary was republished and that it came to the attention of researchers.

13.Van der Walt was a member of the Reformed Church, which is a smaller church that is in some ways more conservative than other reformed churches in South Africa. They, for example, sing only Psalms and reject hymns because singing in Africa. They, for example, sing only Psalms and reject hymns because singing in
church should reflect Scripture as closely as possible. Cf. De Villiers (2009b) for a discussion.

14.Cf. Waaijman (2002:536) for some background, but also Liebert (2005) for an illustration of the consequences of this insight. literature (the genre of spiritual autobiography) in which people express themself on the subject of his relationship with God. Though it has a prescientific nature, it provides a paradigm for scientific reflection which can be developed to provide systematic and critical knowledge and which is, hermeneutically, about experiential interpretation. Experience 'is processed and held against the light of truth with an eye to the spiritual way' (Waaijman 2002:921, quoting Mina). This reveals the significance of diaries for the study of Spirituality where participatory knowledge is happening on more than one level. ${ }^{15}$

Luckhoff's text conforms to Waaijman's description of a diary: his diary is firstly all about lived experiences. It strongly focused on day-to-day events which he experiences as pastor and chaplain. He records his thoughts about the most diverse information and events relating to his ministry as they unfold over a number of weeks - from short, cryptic notes about what he eats, where he lives, whom he visits, to rather extensive descriptions of special occasions and the last moments of the dying. These aspects are all about his lived experiences and his intimate thoughts about them. The flow of events and experiences during this time determine the nature of the diary. It is not a neatly composed, logically structured text: 'The intimacy of the lived life presents itself in its spontaneity as incoherent, confused, fluid and indecisive. Even the consciousness of time is fluid' (Waaijman 2002:923).

The diary is also a genuine acount of his inner thoughts and feelings about these lived experiences. In the foreword he (1993:2) writes, 'A diary is simply a confidential talk to one's self of one self'. The confidentiality is clear from his observation about how embarrassed he was because of crude parts in his diary that reveal his aggression and anger. His explaination is: 'Stress of circumstances must be held responsible for the many undignified expressions in which the Diary abounds' (Luckhoff 2006:1). He is open and honest about such undignified passages, but they must be shared in order to reflect the fullness of his spiritual journey. This illustrates the diary's integrity. It gives the reader an authentic insight in Luckhoff's intimate thoughts about his own spiritual journey.

The way in which Luckhoff noted these lived experiences, reflects more of his Spirituality. His diary represents a spiritual quest for the truth. From the beginning of his ministry, Luckhoff reveals a maturity which brings him to understand the true nature of the camps and the implications of the war for his spiritual journey. The day of his arrival

15.Liebert (2005) has written an essay on practice in Spirituality which offers perspectives that researchers on Luckhoff's Reformed Spirituality will have to consider on a next level. Once one has studied the praxis Luckhoff's Spirituality, one has to consider to what extent and how that is participatory knowledge, opening a space in which the researcher experiences the experience he or she is discussing. She observes (2005:507) that Spirituality researchers work 'almost exclusively with texts' of all kinds, asking about the lived experience of the text and that gave rise to it but also 'its experience in me and in my students' There is and that gave rise to it, but also 'ts experience in me and in my students. There is more: In the light of this discussion, we can now further ask: what new experience is created in the act of investigating this text and wrestling with its provenance, interpretation, and existential usefulness? What experiences of my own would help me enter faithfully into the world of this text? What shared practices would help us come to understand this text and its world and ourselves as interpreters? All these questions reveal the dynamic and multilayered nature of the process
of interpretation. Waaijman (2002:921) developed such remarks in terms of mystagogy. 
he noted that the 'thought suggested itself the very first day that I might desire, in after years, to recall my experiences in Camp, and so I decided to keep a diary'. He understands that events will affect him for life. He therefore carefully writes down his 'doings of the day', first as he walks from tent to tent, scribbling information in a pocket note-book and then copying the information to his diary in his own tent late at night, 'before retiring' (1993:1). Not only his record-keeping, his honesty about his own feelings, his embarrassment about parts of its contents, but also the tone and contents of the diary confirm the general impression that it is a work of quality which provides the reader with an authentic text and that it is regarded by Luckhoff from the very beginning as part of his spiritual path. In the writing of the diary he takes his own spiritual needs into account, even though they may only confront him later on in life. He does so with integrity, ${ }^{16}$ consciously and spiritually aware of the need to experience his faith truthfully.

The diary is even more valuable because of how Luckhoff recorded events. The way in which he did this, reveals a spiritual process of appropriation which is characteristic of diaries. He (2006:1) relates how he wrote the diary during the evenings, 'consulting' notes he made during the day. This means that he, even though he 'scribbled' the notes 'hurriedly', was writing from the prespective of distance to what had occurred. This distance, ex eventu, but also in the solitude of his tent and thus his own space of home, allowed for perspective. In the act of writing, then, the diarist is empowered, even on an unconscious level, to think deeper about events in order to integrate them in his spiritual journey. The distancing is in itself a spiritual act, since it helps to uncover the significance of events. By selecting, omitting and recounting his experiences in writing, he is, furthermore, listening and entering into a dialogue with himself about his experiences. In doing so, he clarifies his own identity amidst the lived life. The diary thus provides one with Luckhoff's struggle with events that affected his faith and that he needed to make a part of his spiritual path.

Finally, it is an indication of the nature of his Spirituality that Luckhoff decides to record, and then, to also publish the diary about his experiences. He feels from the start of his work the possibility that some time in the future he would want to recall his experiences. These are thoughts of someone who is traveling his spiritual journey in full consciousness. When he reflects on his faith, meditating on its role in his life, he therefore desires authenticity. He has to consider his lived faith in the proper light, with proper documentation. With this, Luckhoff is involved in self-hermeneutics, which is an exercise in being oneself. His life becomes experience, in the sense of Dilthey, who noted, that 'something becomes experience when its having-been-experienced has a special emphasis which confers a permanent significance upon it'. It is an 'initiation into being personally by-and-for oneself' ${ }^{17}$ It is, however, not a significance that Luckhoff finds in himself. He writes down his experiences of faith, his life with God, in order for it to be rethought at a later stage of his spiritual

16.Luckhoff (2006:2) states that he did not leave out any part of the diary so as not to 'mar its integrity'.

17.Cf. the full discussion in Waaijman (2002:925; cf. also 921-945) journey. The significance is to be found in his ongoing reflection on what made life meaningful in his spiritual journey with God.

His faith brings him to wrestle with his experiences and, finally, to share it with others. He accounts for his experiences as mystagogue by reading them in the light his intimate relationship with God, thereby underlying its relevance for all spheres of life. The diary in itself is a perfect illustration of the role of praxis in Luckhoff's Spirituality.

\section{Spirituality and the praxis of politics in Luckhoff's diary}

Spirituality is about experienced faith, that is, about divine and human realities that take shape reciprocally, as Waaijman (2002:426) describes it. This implies that it has to do with a relational process. Faith is experienced in ever new and deepening ways. As people journey in faith, they live out of an initial transformation, ${ }^{18}$ but this first transformation continues in a life long process. The interior life of a believer is continuously tested, refined and deepened in a process of spiritual growth. ${ }^{19}$

The diary of Luckhoff reflects the transformational process in several ways. One notices his sense of calling in his willingness to work in the by then notorious concentration camps. His relationship with God brought him to his commitment to serve others as pastor and mystagogue. In the camp, he experiences how his mystagogical work brings about changes in the lives of people. ${ }^{20}$ He grows spiritually to such an extent that he appropriates seminal notions of his faith for the first time in his life - even confessing that he understood the meaning and value of his religion and of love for the first time only when confronted with his experiences in the camp (Luckhoff 2006:20). ${ }^{21}$ The pastor is transformed by his transformative work. In this sense, his Spirituality reflects what Frohlich described as:

Transformation is not only a transforming relation between God and an individual; it is the transformation of the individual as an intersubjective being, and, therefore, of all the relations in which that individual participates. ${ }^{22}$

(Waaijman 2002:456)

18.This transformation process is multilayered. It has to do with transformation in creation - the constant awareness of being in God's hand, the transformation in recreation - a restoration of the divine-human relational process and an ever deeper understanding of God's will, the transformation in conformity - a recovering of the original form of man and the image of God, the transformation in love and in glory. Cf. Waaijman (2002:427-481) for a full discussion. These perspectives can only be mentioned here in order to illustrate various dimensions of Spirituality. In the following discussion only some aspects will be used to understand the Spirituality of Luckhoff's diary due to limited space.

19.For the gradual spiritual growth in Calvinist Spirituality, cf. Lane (2005:163) where he refers to Calvin's discussion of the life of the Spirit in his Institutes (chapters $6-10)$. Important is Spohn's remarks $(2005: 281)$ that one should remember that the cross of Christ, as central analogy for the path of discipleship, is 'starkly that the cross of Christ, as central analogy for the path of discipleship, is 'starkly
disjunctive'. In that sense it reveals its essential place in the inauguration of God's reign.

20.Mystagogy is the discursive sharing of transcending, intimate and personal experience of God. For the rich nature of mystagogy, cf. Waaijman (2002:870-942) whose remarks deserve the be explored in more depth to understand Luckhoff's Spirituality better.

21.Luckhoff's remark that he discovered the meaning of religion and love during his first fourteen days in the camp, is a fascinating example of the role of experience in Spirituality and points towards the heart of the discipline. It also illustrates the key role of self-implication in Spirituality. For a further discussion, cf. the valuable key role of self-implication in Spirituality. For a further discussion, cf. the valuable observations of Liebert (2005:496-514) on the role of practice in Spirituality and,
for the purposes of this essay, her discussion of Waaijman on 511. Cf. De Villiers (2006).

22.Quoted by Waaijman (2002:456) 
All this illustrates a characteristic feature of contemporary Spirituality. It is no longer identified with the ascetic practice that is sometimes associated with individuals who withdraw from society and form their own communities, away from everyday life. It has to do with one's transformative actions and involvement in one's context and in the world. ${ }^{23}$ 'The active, "worldly" dimension of Calvinist piety', as Lane (2005:163) called it, is especially a characteristic feature of Calvinist Spirituality and it was like that from its beginnings:

The Calvinist or Reformed doctrine of vocation called laity and clergy alike to incorporate every sphere of their life into Christ's service, seing the Christian life as more a matter of engagement than withdrawal.

(Lane 2005:163) $)^{24}$

This is particularly true of Luckhoff's diary, which shows how his faith is inextricably bound to daily life and experiences. Three dimensions of his diary will now be discussed in order to explain this in more depth.

\section{Work ethic}

Weber's famous discussion of a Calvinist work ethic (1959:120-121) has provided an important interpretive key to understand Protestantism. ${ }^{25}$ His remarks about the way hard work was considered part of a person's calling and a visible sign or result of salvation are helpful to understand Luckhoff's Reformed Spirituality as well. Luckhoff's diary reflects the image of an active, austere, and hard-working pastor. He practically spends the whole day visiting people in their tents, conducting the one funeral after the other, supporting the ill in hospital whilst fulfilling his normal pastoral responsibilities like church and prayer meetings.

Luckhoff's Reformed work ethic and the Spirituality in which it is embedded, is best illustrated by a unique passage in his diary. In the passage Luckhoff writes down his perceptions of the ministry of his colleague in the camp. With admiration he notes (Luckhoff 2006:30) how 'this good man slaved ever since the Camp has been here, day after day, indefatigably' adding, significantly, 'out of pure goodness and charity'. One hears the echoes of Reformed teaching of good works out of faith in these words. In one of the few footnotes to explain the contents of his diary, he explains this in more detail: 'Mr. Becker used to come over every afternoon ... How faithful he was! How well I remember the little figure in black flitting hither and thither among the tents'. He ends with the remark that he, when he saw Becker entering the tent, 'many a time ... smuggled' into it 'just to learn from him how to pray'.

Clearly the remarks of Luckhoff about Becker's ministry, whose own Spirituality is also revealed in his desire to

23.Cf. Waaijman (2002:651-658) for an informed discussion. It is interesting to note that Spiritualities that are close to Reformed Spirituality, have involvement in the world as a key characteristic of faith. Cf., for example, Randall (2005:291, referring to the social involvement of early and also later Evangelicals).

24. He refers to various examples, amongst other from Calvin's ministry in Geneve, that show 'the Calvinist spirit has been recognized as actively engaged in the transformation of culture', adding, 'Reformed Christians possess an innate suspicion of other-worldliness'. Cf. also Cornick (2005:534) who links the motifs of discipleship and the priesthood of all believers with the notion of engagement with the secular.

25.Note, however, Lane's (2005:164) valid remark that Calvinist emphasis on frugality, simplicity and the practice of charity is an important correction of capitalism. learn how to pray from Becker, show the ideals and values he would have appreciated for his own ministry. Becker represents for him the example of the true mystagogue someone who is a spiritual example that he wants to emulate and who lives a prototype of the Spirituality which he seeks for himself. ${ }^{26}$ For him, moreover, like for Becker, it is not the work in itself that counts, but that the work is done for the behalf of others and to be with others.

Luckhoff's own work ethic is further illustrated by noting one of his daily rounds. On Friday 23 August, his third day in the camp, he writes down, for example, all his visits like he did for the rest of the time. The information reveals the extent of a 'normal' day in his pastoral ministry. Having risen early and after having shaved ${ }^{27}$ in the stream between the camp and the village, he observes, first of all, clearly moved by the scene, how an old man assists his frail wife from the hospital to their tent. His first visit is to a family whose son died the previous night.

After lunch he unpacks three boxes from the Red Cross. He then visits a dying child with a mother sitting next to her bed in deep mourning. In a next tent, he prays for a family whose mother is dying. He also visits a woman whose husband died from a heart attack the previous night. After visits to several other sick children, he enters a tent where he hears someone coughing. Inside the tent he finds a husband whose wife had died and three sick children. The youngest was dying. In a next tent, he consoles a woman after her child's death. He then conducts seven funerals.

After the funerals, by which time his throat is hoarse, he returns to his tent to meditate, clearly exhausted by the day's work and in need of some relief. And yet, he finds it necessary to visit a dying child. At this point, he exposes his inner feelings about the misery with which he is being confronted. $\mathrm{He}$, as he describes it, made a fool of himself when he broke down and cried during his prayer. He adds: 'The helplessness in presence of Death!' (Luckhoff 2006: 4-5).

Other notes indicate that he had a couple of conversations with several friends and people in the camp. Before the end of the day he hears of the death of another child and of 14 corpses in the mortuary of the hospital. When he retires, he writes, he listens to strains of Psalm-singing (Luckhoff 2006:4-5).

This routine would become only more intense over the following weeks as he visits and buries more and more people. On September 19 Luckhoff writes, 'I have been here just a month, and have, during that time, done nothing but visit sick and dying'. He never lets up, though, because this is what he expects and what he pursues as pastor. His work ethic does not allow him to give up. He is so dedicated that he is often frustrated when the task seems too big. '(T)he

26. Becker also mentions (1993:76) Luckhoff's dedication and hard work. There seems to have been a good relationship between the older and younger men with mutual appreciation for each other's ministry.

27.Remarkable and enigmatic is his reference to tears: 'Early bird: wash spruit; first shave (tears)'. 
work is the hardest in the world' (Luckhoff 2006:5), or 'work here for 10 men':

no chance alone; no show; the helplessness of it all! and there are hundreds sick and dying that I know not of, and that I could not visit even should I know.

(Luckhoff 2006:6)

On 27 Augustus he writes: 'Extremely difficult task, for the conditions all around are most lamentable depressing.' $\mathrm{He}$ speaks of how 'incessant weary' he is (Luckhoff 2006:6). Even more depressed is he because the implications for his ministry: his visits and pastoral work leave him little time to prepare his sermons. The following remarks illustrate the consequences of his heavy work-load: 'No time to prepare; I tremble when I think of what I venture in coldbloodedness', and 'Recklessness, preached twice to-day without preparation ... simply compelled to' even though, he adds, he 'made services short: fifty-five minutes' (Luckhoff 2006:11, $15,16)$.

Two major aspects qualify his work ethic more precisely. One recognises in Luckhoff's work ethic, first of all, that it is about reaching out to others in solidarity and oneness. He works in order to promote a spiritual bond with others. His Spirituality is a graphic illustration of what Waaijman (2002:443) describes as 'The soul has the capacity to step out of itself and to be by the other'. It is a solidarity which involves his whole being. The being with others reflects Biblical images which Waaijman (2002:444) describes as, 'personal contact, communion, intimacy'. Luckhoff thus displays empathy and sympathy with others that reflect the close bonds between him and those whom he serves. ${ }^{28}$

In all his activities, he is, secondly, the typical Reformed pastor of his time who regards the preaching of the Word as a major task and who visits his flock with the Bible in the hand. Scripture is the focal point in his ministry. This is typical of Reformed Spirituality which is, as Lane (2005:163) noted, 'inescapably' biblical. ${ }^{29}$ His work is about proclaiming the Word. Regularly he refers to the worship services he held or plans to hold - a task he takes seriously and which frustrates him if he has not had enough time to meditate and prepare for it. His sermons are central to his work, reflecting the 'sacramental nature' of preaching in the Reformed tradition. ${ }^{30}$ Time and again, he lists the particular texts from Scripture he has selected for his services and funerals. The ministry is about proclaiming Scripture, but it is also about bringing the flock to develop their own spiritual bond with Scripture. ${ }^{31}$

28.On the notion of empathy in mystagogy of Waaijman (2002.935-942). Referring to Husserl and Stein, he describes it (p. 934) as 'a form of cognition by which I, in my own understanding, discover the other as an alter ego, put myself in her shoes and sense how she experiences reality in her own unique way'. Note, however, how he distinguishes (p. 939) it from sympathy, where one moves beyond empathy, agrees with the other's reality and identifies with it.

29. He writes, 'Given the importance that the Calvinist tradition attributes to mystical union with Christ as the central project of the Christian life, preaching becomes basic to that process in offering what amounts to the "real presence" of Christ in the preached Word. Calvin insisted that "God is nigh to us, face to face" in the mystery of preaching ... Calvinist piety is thus inescaply biblical'.

30.Cornick (2005:533-534) refers to a remark of Calvin that refusing to listen to godly preachers was 'like blotting out the face of God which shines upon us'. The importance of his sermons is clear from Luckhoff's diary. He spends much time in preparing them in prayer, meditation and reflection. Cf. further below.

31. He recounts (2006:12) a telling incident in this regard, about a dying girl who, when he repeated a verse from Scripture, she would say the lines in advance.
His many daily visits are also typical of the Reformed piety of 'huisbesoek' [house visitation] during which people are encouraged through Scripture readings and prayers. The Reformed theological emphasis on Scripture brought the Reformers to encourage devotions which focussed on Scripture. This is what Luckhoff also sought in his reaching out to others. These private devotions ${ }^{32}$, which included the singing of hymns and prayers, were regularly held in tents..$^{33}$

\section{A Spirituality of justice and dignity}

Luckhoff's Spirituality comprises more than pastoral support and spiritual formation. It is complemented by a strong stance against injustice, cruelty and callousness, which is a recurring theme in the diary. He regularly expresses his anger and frustration about the insensitivity and cruelty of the camp authorities. With indignation, for example, he speaks of the callousness of the doctor who treats his patients badly, ${ }^{34}$ of the camp authorities who arbitrarily and unjustly refuse permits to camp residents to travel to see their loved ones and who have no qualms about serving rotten meat to them. ${ }^{35}$

He is himself also by times a victim of such unjust and inhumane actions. At some stage he finds his tent 'unceremoniously pulled down and removed during his morning visit' (Luckhoff 2006:65). This act confirms his perceptions of the authorities' attitudes. He openly records his irritation and anger - not so much because of his own discomfort, but more because of the callousness and disrespect of the act:

Ah but it was enough to rouse and irritate a person. But what an utter absence of the faintest traces of some respect and deference. There are men whose cold-blooded brutishness and irreverence knock one over completely - nay I verily believe some glory and revel in the act of making a fellow-creature miserable.

(Luckhoff 2006:65) $)^{36}$

He does not take this lying down. Fearlessly he responds to this incident by taking drastic action, sending 'his resignation on the spot'. The effect is dramatic and shows the measure of respect accorded to him by camp authorities. It 'made a mighty change, and there were explanations and apologies etc., and at 1 p.m. I had another tent, and my resignation safe in drawer' (Luckhoff 2006:66). At another time he records

32 . Cornick (2005:534) refers to the Reformers who encouraged daily private worship centred on Scripture reading.

33.Luckhoff (2006:4-5) records how, late at night, he heard strains of Psalm-singing in the camp. These Psalms were standard part of Calvinist hymn books. They were so important that a group of Reformed Christians broke away from the larger Dutch Reformed Church in South Africa because they refused to sing hymns. They wanted Reformed Church in South Africa because they refused to sing hymns. They wanted to sing only Psalms because they came from Scripture, whilst hymns were free
compositions with religious contents that were not taken literally from Scripture.

34.Although he retained good relations with one of the doctors and mentions how, as a result, he was often willing to accompany Luckhoff, even at night, to desperate cases, he mentions (1993:15) how the doctor was 'universally detested', 'feared' and 'ultimately ... knocked down by an irate husband'.

35.Luckhoff notes (1993:12) that he would not have given the meat to a dog: 'When thrown against a wall, for instance, it would stick'. This, he adds, revealing his fairness to give credit where it is due, was not the case with flour which 'was good for the bread was usually excellent'. He records how women were imprisoned after their violent protests against the meat rations.

36.Cf. the similar remarks of Becker, the colleague of Luckhoff, who writes (1993:79) about Bethulie as the worst possible camp and remarks how people seethed with anger at the treatment of the residents. 
how he 'boiled over' (Luckhoff 2006:12) when his letters were returned by the camp censor. Once again offering his readers an insight in the characters of the people who were in charge in the camp, he describes the censor as 'such a little snob, who is too big for his boots'. Once again he takes action. His sense of justice does not let him take this lying down. He notes, 'Pinpricks; will fight it out tomorrow' (Luckhoff 2006:12).

His anger against destructive actions cuts both ways, as is evident from the times that he also gets upset with his flock when they undermine the dignity of the dying by making a scene at deathbeds. He considers even such seemingly innocuous actions as undignified and contra-productive. Several times in his diary he castigates people who gape disrespectfully at the dying on their deathbeds. He describes how he boiled over, a 'roaring lion, because of the crowd of inquisitives; stood at the doorway and addressed them; said I was ashamed of their conduct' (Luckhoff 2006:13). He angrily writes, 'I am vexed in my soul and feel as though I could knock down everyone of them' (Luckhoff 2006:15)! ${ }^{37}$

His attitude on this issue is well motivated. He finds the underlying negativity unacceptable. Some folks 'unconsciously delight to wander in the somber shadows of life'. It is not only that they get drawn in into an atmosphere of negativity, but it also affects the sufferers. A 'long-faced despondency' has a bad effect on the ill (Luckhoff 2006:11).

In all these matters he is the practical person, who cares for his flock by challenging unjust actions that humiliate and dehumanise people. Some of these actions have political implicatons, because they challenge the authorities. Others are religious in nature, focusing on an authentic faith that respects the dignity of others. All of these show, however, that his Spirituality is not escapist. Such an attitude reflects the general character of Spirituality that seeks to be visible in the praxis of faith and in the struggle against evil. Faith and life and/or praxis are inextricably bound. Life is the space where faith has to be lived and where faith shows its power. Once again this reflects Reformed spirituality, mentioned previously, that fights for a world in which people can live a humane and dignified existence and in which the reign of God is established. It is a struggle for justice, for a world, transformed from its deformation into a world that reflects the image of a just God. ${ }^{38}$

\section{Spirituality and politics}

Luckhoff's engagement with his secular context, may seem to some to be restricted to non-partisan and non-political

37 . His strongest outburst in the diary (1993:11) is about 'a crowd around a tent doorway, watching the end. Yesterday I lost my temper at (tent) 35 , and gave it hot all round. Such barefaced curiosity is revolting; I hate it'.

38.For a perspective on the many links between Spirituality and politics, cf. Waaijman (2002:212-232). Reformed Spirituality shares with many other forms of link and of the appreciation for the close link between the two. Ilustrative of this the two, is the work of the two, is the work of Solle. She regards, as Waaijman (2002:230) points out, mysticism in the first place as love for God, but adds that the desire for God is focused on the world and daily praxis. matters. His diary does not contain many explicit political pronouncements. There are, for example, few references to freedom for the Boer republics, to the land question, to the enemy as colonial power and to a struggle for political freedom. This is especially striking when his text is compared with the works of Reverend Becker and Rensche van der Walt who often and explicitly raise political matters.

Luckhoff does, however, mention politics indirectly on two occasions. These two incidents are sufficient to point out where his sympathies lay. On one occasion, he discusses a 'girl's prayer meeting' where he:

regulated prayer somewhat: first for our own special needs, second and third for our camp-sick, weary, sorrowful, careless, unconverted, hospital; fourth and fifth, relatives and friends far away; Land en Volk.

(Luckhoff 2006:64)

Thus, in an open meeting, he does propose prayers in loaded terms for 'land and people' [Land en Volk]. ${ }^{39}$ One should not, therefore, judge his views on politics in terms of the number of times he discusses political issues in his diary.

His sympathies are made clearer at one point in his diary when he refers with much disdain to joiners. The same anger and indignation against the cruel authorities permeate his language: 'Wonder if a worm wouldn't have more selfrespect!' They 'make themselves despicable and contemptible' to the enemy and bring 'deep-down humiliation' to their own people (Luckhoff 2006:54).

Luckhoff had good reason to keep a low political profile. Chaplains had to toe the line, as is evident from what happened to Luckhoff's colleague, the Reverend Becker, who was also the pastor of the local church in Bethulie and who, together with his wife, were removed from the camp after a letter from one of the women in the camp to a relative was found in his possession. ${ }^{40}$ Though Luckhoff knew he had to play according to the rules and avoid controversiality, or even imprisonment, he makes it clear that this submission was a matter of conflict for him. It affects his self image and causes him to feel humiliated. Whilst he goes out of his way to placate authorities, ${ }^{41}$ he writes (2006:27), 'This was my daily dilemma: Speak out and protest, and be removed or imprisoned - hold silence and act the coward, and remain in work'. With obvious pain he adds, 'And I chose the latter'. For him it was a matter of remaining with his people in their trauma. He was willing to swallow his pride and of being regarded as a coward for the greater cause of ministering.

39.The two words are, significantly, capitalised.

40.Luckhoff himself was in trouble because of two letters to Rev. Robertson and his mother in which he referred to the rotten meat and the arbitrary manner in which camp authorities distributed relief donations. He was reprimanded and the letters destroyed. Cf. Luckhoff (2006:17). He also refers (2006:27) to a Reverend Steytler who had to leave his post for political reasons.

41.Cf the indignant remarks by Becker (1993:75-76). He was allowed to resume his work after Luckhoff left. For the position of chaplains, who had to be British subjects or neutral, cf. Britz (2007:31). Luckhoff (2006:17) was adamant that he should have the confidence of the authorities. He experiences one of the 'bitterest' days when the Superintendent is angry about a letter he wrote. He is willing, he days when the Superintendent is angry about a
writes in his diary, to resign if he lacks their trust. 
For him, therefore, the spiritual needs of his flock were of paramount importance. It requires one to hold back in order to focus on the real issues.

Luckhoff may be accepting of the officers' authority, but he does not hide his true feelings about them. It did not take him long after his arrival to sum them up:

and I determined to have nothing to do with these men: to ask no favours, and to be under no obligation to them for anything. Of course, there came days when I was forced, under stress of circumstances, to eat these resolutions.

(Luckhoff 2006:18)

Here too, though, he indicates how deeper considerations would bring him to give up his decisions.

This attitude is an indication of Luckhoff's ability to discern what is important. On the one hand, it means compromising one's position for the sake of the well-being of his flock. But on a higher level it means that he was seeking to find good in a situation of evil. There is in the introduction to the diary a telling indication of this ability to integrate politics within a larger spiritual framework and accord it its rightful place. The remark illustrates his Spirituality which empowers him to see beyond mere mundane, exterior matters like politics and transform situations of brokenness caused by it - however important they may be. This happens when he reflects on the publication of his diary. 'Cui bono?', he asks (Luckhoff 2006:2) when he wants to motivate the publication. ${ }^{42}$ This seemingly simple question reflects on how he regards the need for faith to pursue good at all times, even in extreme times of war. It is, therefore an attempt to seek the divine will. Here one sees spiritual discernment at work, ${ }^{43}$ that is, acknowledging the sovereignty of God, also against evil, asking what serves the glory of God and seeking the well-being of others even on such a simple level as publishing a diary. ${ }^{44}$

His answer is equally spiritual in nature. What stands out about the war, he notes, is the nobility of the sufferers. Ultimately, faith does not speak about the ministry of dedicated pastors, nor does it wallow in the cruelness of the enemy or the senselessness of war. It is rather the nobility of the victims that must be remembered as enduring legacy of lived faith. In a key sentence he writes, 'Cannot we sometimes forget the inevitable political aspect of things and see beyond it into the human?' (Luckhoff 2006:2). ${ }^{45}$ This use of the word 'human' which he sees as a higher good than politics, is

42. He writes, "Cui bono? is of course, the question which must be faced" (Luckhoff 2006:2).

43. His discernment for what is the real issue, is indirectly also shown when he tries to help someone find wood for a coffin, noting, with some shame, that he practically had to steal wood (cf. Luckhoff 2006:46, cf. also 11, 12, 15), Luckhoff writes (2006:10), 'It is pitiable' to see a husband who wants to bury his wife, 'pleading for boxes which could not be given'. He understands the 'great outcry', but then adds, 'And yet, after all, will a coffin save the soul?'

44.Cf. Cornick (2005:534) for the focus of Reformed Spiritality on glorifying God.

45.In this respect, Luckhoff's diary is, once again, different from that of Rensche van der Walt in which she often speaks about land and freedom. She repeatedly refers to the British colonisers who should return to their land and leave the Boer Republics alone. She is also more often deeply scornful of the joiners and traitors amongst her own people and women who familiarise with the British soldiers. Cf. De Villiers (2009b) fascinating. The deeper, spiritual moment of the war is for him the 'human'. And the human to him is in this case is about 'Woman's Endurance' and their fortitude (Luckhoff 2006:2). ${ }^{46}$

In his political activities, Luckhoff reveals his Reformation Spirituality which grounds faith in the world and which seeks to live in society in the light of faith. Reformed Spirituality is not escapist. And yet, it also discerns what really matters. Key motifs and deeper spiritual values transcend and transform all exterior, political matters. ${ }^{47}$ It is the human which is, after all, most important.

\section{An Evangelical face of Reformed Spirituality}

Luckhoff's diary provides a perspective on how Reformed groups experienced their faith in a time of war when faith is of utmost importance. In this situation socio-political issues are also significant. Luckhoff understood the needs of people and supported them in an indefatigable manner with an exhausting work schedule driven by his Reformed work ethic. At the same time he also understood that they needed more than visitations. He felt that his faith required from him to support them in their most basic of needs - even to the point of cleaning their tents and supplying them with wood for coffins. ${ }^{48}$ He went further and also fought against the injustice and humiliation to which they were subjected. He identifies with the political aspirations of his flock, strongly rejecting the way they are treated, but it is their spiritual journey which is the most important matter for him. Ultimately it is the deepest spiritual values that both drive and relativise this involvement with the world and life.

46.Botha (1993:1-53) describes how women kept farming on the home front, how they supported their husbands and sons on the battle field morally and with proviand, sometimes even joining them to fight on the battle front, how they nursed the sick and wounded, manufactured clothes, kept education going, set nursed the sick and wounded, manufactured clothes, kept education going, set p information networks and took care of finances. These actions were often eligiously motivated. Botha (1993:21-22) discusses how religious Afrikane women were. This would be in line with the role of religion in society generally, as Britz (2007:28-30) spelled out with a number of interesting examples. Luckhoff's view of the role of women was widely shared by many others. Women made such an impression that they were commemorated in the unique Womens' Monument in Bloemfontein and the Voortrekker Monument in Pretoria. The fame of women from the Boer Republics was known far outside their countries. Emily Hobhouse (1923) also dedicated her first book on the war to the women of South Africa 'whose endurance of hardship, resignation in loss, independence under coercion, dignity in humiliation, patience through pain and tranquility amidst death kindled the reverent appreciation of the writer, and has excited the sympathy of the world'. Cf. De Villiers (2009b) and Giliomee $(2004: 190-191,211)$ for the role of women in the Anglo-Boer war. For historical documents about the treatment of women in the war, cf. Raath and Louw (1993). They record statements under oath of women and children who were attacked, assaulted, raped, driven from their homes, subjected to destruction of their property, exposure to extrem fonditions and incarsected without trial.

47.For the fortitude of women in the Bethulie camp, cf. Becker (1993:80). It is important to note that the inner strength of Boer women was at times quite
remarkable. There are quite a number of examples, though, where Boer women remarkable. There are quite a number of examples, though, where Boer women only their own prejudices against their enemies, but also defying the criticism of those who disagreed with them. Botha (1993:7-8) discusses the example of a Ms Roos who handed out food to soldiers who were weakened by lack of food. She writes, 'Some of my friends were very angry with me for thus aiding the enemy, but I knew it was my duty by divine precept to feed my starving enemy, if I could. I could never, I thought, have forgiven an Englishwoman is she had turned a starving son of mine from her door'. It is this kind of humanity which is present in Luckhoff's remark about the human that relativises the political. Especially noteworthy is how remark about the human that relative Roos motivates her action by the telling phrase, 'by divine precept. It reflects the spirituality which characterizes the attidudes of some women to their enemies
from whom they had to endure such cruel suffering.

8. He notes (2006:19) how filth and stench in some tents were unbearable and then adds, 'ventilated tent myself'. In a footnote he refers to his 'great zeal' about cleanliness so that he was rather severe towards people about it. 
There is, however, a final aspect that deserves attention and that has to do with the way in which Luckhoff's diary reflects a new phase in his spiritual journey with a new understanding of his identity. Luckhoff's Reformed Spirituality reflects a particular evangelical tradition within the Dutch Reformed church with its emphasis on repentance from $\sin$, a life of holiness and a missionary zeal. ${ }^{49}$ One anecdote illustrates this. He recounts (2006:39) how he visits someone with whom he had long talks before. He notes that he is afraid she is still ignorant of a 'primary step' which he then explains as 'reconciliation with God'. If this refers to a key phrase in Reformed Spirituality and reflects Biblical language, his following explanation offers more insight in the evangelical Spirituality in which such language was embedded. He writes that he 'spent a long time while making the way of salvation clear' to her. Intriguing is his following remark, where he seems to point out that she was from an orthodox Reformed tradition. He comments about the residents of the tent: 'Doppers'. Because of some chance intrusion he was prevented from reading to her a hymn (Doppers or Reformed Church members do not sing hymns, only Psalms). He ends the entry: 'Narrow shave'. The hymn he wanted her to sing is telling. It reads, 'Come ye all, sinners come, what dare hold you back'. It is a hymn with a clear evangelical character. It reflects conversion language and a call to repentance that suggests altar calls from the Wesleyan or Methodist traditions (Luckhoff 2006:39).

The roots of this evangelical Spirituality of Luckhoff are found in his family context and in his theological training in which various Reformed traditions were merged. Some of these Reformed Spiritualities were characterised by revival meetings that focused on personal conversion. ${ }^{50}$ It is often linked with the Reverend Andrew Murray, who is known for his revivalist ministries. ${ }^{51}$ Sometimes it is described as having a subjective character that differs from Reformed Spirituality ${ }^{52}$ with a more objective character and with more attention to the Christ of faith than to conversion and the pursuit of holiness.

Brummer (2010:35) provided more light on some of the influences which Luckhoff underwent when he described the history of three of the prominent church leaders in the 19th century (Andrew Murray, John Murray and Nicolaas Hofmeyr). Whilst other South Africans (T.F. Burgers and

49.Cf. Giliomee (2004:208) who takes over the description of this movement as ' vital religion of the heart'; cf. Britz (2007:30-31). There are, in this regard, major vital religion of the heart'; cf. Britz (2007:30-31). There are, in this regard, major
similarities with Methodist Spirituality (cf. Kingston 2005), Evangelical Spirituality (cf. Randall 2005), Pietism (Hanson 2005) and Puritan Spirituality (cf. e.g. Lane (cf. Randall $2005: 520$ ).

50.Various expressions are used to describe this form of Reformed Spirituality. It refers to the well-known Dutch motif of 'bevindelike' Spirituality which reflects engaged experiential or lived faith. Britz (2007) uses the term 'evangelical', which would cover some of its meaning - though 'evangelical' is an umbrella term which is linked with various forms of Spirituality.

51.Cf. Giliomee (2004:208). As example of this 'evangelical' approach by pastors in camps in general, Britz (2007:30-31) refers to preaching, prayer meetings, altar calls, decisions for Christ, repentance and conversions, even revivals.

52.Rensche van der Walt would be an example of the more objective form of Reformed Spirituality. Her Spirituality was influenced by the prominent Calvinist Reformed Spirtuality. Her Spituality was inluenced by the prominent Calvinist 2009b). And yet, she alsonce thats guides the life of God's people (cf. De Villiers $2009 \mathrm{~b})$. And yet, she also reflects a Reformed Spirituality that reaches out with much compassion to others with concrete deeds of charity, sharing with them especially material resources.
J.J. Kotze) were influenced by the extreme rationalistic philosophy of Opzoomer and the modernist theologians like J.H. Scholten and A. Kuenen in Leiden, the Murray's and Hofmeyer's were inspired by the theological society, 'Secor Dabar' in Utrecht which approached theology from the perspective of the Reveil and was heavily influenced by mystical piety and the missionary fervour of Von Zinzendorf and the Reveil in the Netherlands. ${ }^{53}$ Their vision was that faith 'is not a thing like a theory but a thing like a love-affair'. John Murray and Nicolaas Hofmeyer were appointed as the professors at the Theological Seminary in Stellenbosch where Luckhoff was trained. He must have been influenced by the evangelical tradition which these influential people consciously embraced and articulated within the church.

Luckhoff's diary reflects both the power and versatility of Reformed Spirituality and of Spirituality in general in his integration of faith and praxis. He wrote his diary within a context of war in which people from Reformed faith addressed the destructive socio-political consequences on their community members. Leaders and members from Reformed faith communities had as main aim to support those who were victims of war spiritually and physically. In this they shared a common Reformed Spirituality which was driven by the conviction that faith needs to be lived. Luckhoff's evangelical concern for conversion and repentance, therefore, remained linked with and ultimately overshadowed by his concern for the practical needs of people. ${ }^{54}$ In his case, action and praxis were heavily invested with socio-political meaning.

\section{Acknowledgements Competing interests}

The author declare that he has no financial or personal relationship(s) which may have inappropriately influenced him in writing this article.

\section{References}

Arendt, H., 1958, The Human Condition, University of Chicago Press, Chicago, IL.

Becker, H.C.J., 1993, 'Die Konsentrasiekampherinneringe van Ds H.C.J. Becker te Bethulie', in A.W.G. Raath \& R.M. Louw (reds.), Bethulie: Die Konsentrasiekamp te Bethulie gedurende die Anglo-Boereoorlog: 1899-1902, pp. 70-85, Prisca, Welkom

Boff, C., 1987, Theology and Praxis, Orbis, Maryknoll, NY.

Botha, L.A., 1993, 'Die Rol en Ervaringe van die Afrikanervrou buite die Konsentrasiekampe tydens die Anglo-Boereoorlog', in A.W.G. Raath \& R.M. Louw (reds.), Vroueleed: Die Lotgevalle van die Vroue en Kinders buite die Konsentrasiekampe. 1899-1902, pp. 1-53, Prisca, Welkom.

Britz, R.M., 2007, “'Now, What has become of our Prayers and Supplications?" Faith in an Anglo-Boer War concentration camp of 1901', Acta Academica 39, 21-44.

Brummer, V., 2010, 'Hofmeyr en die Mistieke Teologie op Stellenbosch', Nederduits Gereformeerde Teologiese Tydskrif 51, 25-40.

Cornick, D., 2005, 'Reformed Spirituality', in P. Sheldrake (ed.), The Westminster Dictionary of Christian Spirituality, pp. 533-535, Westminster John Knox, Louisvill, KY.

De Villiers, P.G.R., 2006, 'Spirituality, theology and the critical mind', Acta Theologica Supplementum 8, 98-121.

53.Cf. also Giliomee (2004:2006) who also includes the name of J.H. Neethling, a minister of the Stellenbosch congregation and later also a professor at the Seminary as a student in The Netherlands.

54. He was not alone in this concern, for Professor Hofmeyr, his teacher at the Seminary, played a key role in providing for the physical and spiritual needs of the Boer Republics and the citizens in the camps. 
De Villiers, P.G.R., 2008a, 'Towards a Spirituality of Peace', Acta Theologica Supplementum 11, 213-51.

De Villiers, P.G.R., 2008b, 'Peace in Luke and Acts: A Perspective on Biblical Spirituality' Acta Patristica et Byzantina 19, 110-34.

De Villiers, P.G.R., 2009a, 'Peace in the Pauline letters: A Perspective on Biblical Spirituality', Neotestamentica 43, 1-26.

De Villiers, P.G.R., 2009b, 'Tranquility in the Face of Death: Calvinist Spirituality in a Time of War',Studia Historiae Ecclesiasticae 35, 119-139.

Eire, C.M.N., 1990, 'Major Problems in the Definition of Spirituality as an academic discipline', in B.C. Hanson (ed.), Modern Christian Spirituality: Methodological and historical essays, pp. 53-64, Scholars Press, Atlanta, GA.

Gaum, F. (red.), 2007, Christelike Ensiklopedie, Lux Verbi, Wellington.

Giliomee, J.H., 2004, Die Afrikaners: 'n Biografie, Tafelberg, Kaapstad.

Hamman, K., 1965, Dagboek van 'n Bethulie-Kampdogter, N.G. Sendingpers, Bloemfontein

Hanson, B., 2005, 'Pietism', in P. Sheldrake (ed.), The Westminster Dictionary of Christian Spirituality, pp. 490-491, Westminster John Knox, Louisville, KY.

Hobhouse, E., 1923, Tant Alie of Transvaal: Her Diary 1880-1902, George Allen and Unwin, London.

Holder, A. (ed), 2008, The Blackwell Companion to Christian Spirituality, Blackwell, Malden, MA.

Jacobs, F., 2003, Suffering of War - A Photographic Portrayal of the Suffering in the Anglo-Boer War, Kraal, Bloemfontein.

Kingston, B., 2005, 'Methodist Spirituality', in P. Sheldrake (ed.), The Westminster Dictionary of Christian Spirituality, pp. 437-438, Westminster John Knox Louisville, KY

Lane, B.C., 2005a, 'Calvinist Spirituality', in P. Sheldrake (ed.), The Westminster Dictionary of Christian Spirituality, pp. 162-164, Westminster John Knox, Louisville, KY

Lane, B.C., 2005b, 'Puritan Spirituality', in P. Sheldrake (ed.), The Westminster Dictionary of Christian Spirituality, pp. 518-520, Westminster John Knox, Louisville, KY.

Liebert, E., 2005, 'Practice', in A. Holder (ed.), The Blackwell Companion to Christian Spirituality, pp. 496-514, Blackwell, Malden, MA

Luckhoff, A.D., 2006 (1904), Woman's Endurance, Protea, Pretoria.

Pakenham, T., 1979, The Boer War, Avon Books, New York, NY.

Pauw, S., 1946, Die Beroepsarbeid van die Afrikaner in die Stad, Pro Ekklesia, Stellenbosch.
Pretorius, F., 2006, 'Introduction in A.D. Luckhoff, (1904)', in Woman's Endurance, pp. iii-ix, Protea.

Raath, A.W.G. \& Louw, R.M., 1993a, Vroueleed: Die lotgevalle van die vroue en kinders buite die konsentrasiekampe: 1899-1902, Prisca, Welkom.

Raath, A.W.G. \& Louw, R.M., 1993b, Bethulie: Die konsentrasiekamp te Bethulie gedurende die Anglo-Boereoorlog: 1899-1902, Prisca, Welkom.

Randall, I.M., 2005, 'Evangelical Spirituality', in P. Sheldrake (ed.), The Westminster Dictionary of Christian Spirituality, pp. 289-291, Westminster John Knox, Louisville, KY.

Ransford, O., 1969, The Battle of Spion Kop, John Murray, London.

Roten, J.G., 1994, 'The Marian Counterpoint of Postmodern Spirituality', in A.W. Astel (ed.), Divine representations: Postmodernism and spirituality, pp. 1-14, Paulist Press, New York, NY

Schneiders, S.M., 2005, 'Approaches to the Study of Christian Spirituality', in A. Holde (ed.), The Blackwell Companion to Christian Spirituality, pp. 15-33, Blackwell, Malden, MA.

Schneiders, S.M., 2006, 'The Discipline of Christian Theology and Catholic Theology', in B.H. Lescher \& E. Liebert (eds.), Exploring Christian Spirituality: Essays in Honor of Sandra M. Schneiders IHM, pp. 196-212, Paulist, New York, NY/Mahwah, NJ.

Sheldrake, P., 1999, 'The Study of Spirituality: Theological Trends', The Way 39(2), 162-172.

Sheldrake, P. (ed.), 2005, The Westminster Dictionary of Christian Spirituality, Westminster John Knox, Louisville, KY.

Spies, S.B., 1977, Methods of Barbarism: Roberts and Kitchener and Civilians in the Boer Republics January 1900 - May 1902, Human \& Rousseau, Cape Town.

Spohn, W.C., 2005, 'Christian Spirituality and Theological Ethics', in A. Holder (ed.), The Blackwell Companion to Christian Spirituality, pp. 269-285, Blackwell, Malden, MA.

Van Reenen, R., 1973, Heldin uit die Vreemde, Tafelberg, Kaapstad.

Van Reenen, R., 1980, Emily Hobhouse: Boer War Letters, Human \& Rousseau, Cape Town.

Waaijman, K., 2002, Spirituality: Forms, Foundations, Methods, Peeters, Leuven, Paris, Dudley, MA

Waaijman, K., 2006, 'What is Spirituality?', Acta Theologica Supplementum 8, 1-18.

Weber, M., 1959, The Protestant Ethic and the Spirit of Capitalism, Scribner, New York, 